\title{
Cervical ribs in human early life: morphological variability and first identification as a morbidity criterion in a past population
}

\author{
Caroline Partiot $^{1}$ (D) | Mark Guillon ${ }^{1,2}$ | David Peressinotto ${ }^{1,3}$ | Dominique Castex ${ }^{1}$ | \\ Bruno Maureille ${ }^{1}$
}

${ }^{1}$ UMR 5199 PACEA, CNRS, Université de Bordeaux, Pessac Cedex, France

${ }^{2}$ Inrap, Boulevard de Verdun, Le Grand Quevilly, France

${ }^{3}$ Hades Archéologie, Balma, France

\section{Correspondence}

Caroline Partiot, UMR 5199 PACEA, CNRS, Université de Bordeaux, Bâtiment B8, Allée Geoffroy Saint Hilaire, CS 5002333615

Pessac Cedex France.

Email: caroline.partiot@gmail.com

\begin{abstract}
Despite the medical literature on supernumerary cervical ribs in extant adult samples, little is known about their development and occurrence in early infancy. The documentation of cervical ribs in modern samples of fetuses and neonates is indeed affected by ethical as well as technical limitations. The aim of the present study was to investigate their frequencies and morphological variability in the first known archaeological collection of very young children with this anatomical variant. The study sample comes from the 8B-51 necropolis on the Saï island (Sudan) and dates to the Classic Kerma Period (XVIIle-XVle centuries BC). It consists of 64 individuals deceased between 24 weeks of amenorrhoea and 2 years of age. Bilateral or unilateral cervical ribs were found in 27 individuals. A total of 43 cervical ribs were identified, 38 of which are fully preserved. According to these observations, at least $42 \%$ of the individuals have unilateral or bilateral cervical ribs, with an average maximum length of $<1 \mathrm{~cm}$. This frequency is very high compared to those observed in contemporary adult samples (up to $3 \%$ ). First, the comparison of our results with biological and genetic research demonstrating the link between the occurrence of cervical ribs and a reduced chance of survival during infancy allows the first identification of this trait as an indicator of morbidity in an archaeological collection, a morbidity to which a genetic homogeneity or even endogamy could contribute. Second, the number of ribs studied makes it possible to propose a morphological classification based on the general shape and the shape of the articular facets, classification that can be used tos refine the analyses of the trait in future samples.
\end{abstract}

\section{KEYWORDS}

developmental anomalies, discrete traits, Kerma, neonatal death, risk marker, Sudan, supernumerary rib

\section{1 | INTRODUCTION}

In humans, a cervical rib is a supernumerary rib occasionally arising on the seventh cervical vertebra. It can be unilateral or bilateral (Adson and Coffey, 1927), and the distal end may be free or articulated with the first rib (Cave, 1975). Its proximal end is clearly distinct from the vertebra, a characteristic that distinguishes it from apophysomegaly, i.e. the elongation of the vertebral transverse process (Le Double, 1912; Ray et al. 1953; Merks et al. 2005; Bots et al. 2011; Viertel et al. 2012; Chan et al. 2013). The cervical rib is influenced during its development by surrounding muscles, nerves and vascular structures. In adults, it is asymptomatic in $90 \%$ of cases 
(Demondion et al. 2006), but sometimes the subclavian artery and nerve can be compressed between the rib and the anterior scalene muscle, which can cause blood vessel stenosis, pain and paresthesia, symptoms that are sometimes referred to as thoracic outlet syndrome, or TOS (Ray et al. 1953; Bertelsen et al. 1968; Sanders and Hammond, 2002; Cubuk et al. 2010; Chandak, 2014; Erickson, 2015; Hussain et al. 2016; Spadliński et al. 2016; Jiang et al. 2019; Morel et al. 2019). The occurrence of symptoms is highly variable, depending on the shape, size and relationships of the different anatomical structures, but it generated a considerable scientific interest for the incidence and morphological diversity of cervical ribs in adults. This interest dates back to late antiquity, with the first description of the anatomical trait by the Greek physician and philosopher Galen (Boudon-Millot, 2012). Numerous studies have then focused on this topic since the 18th century (Hunauld, 1742), with synthesis and anatomical descriptions published by Gruber (1869), Le Double (1912) or Patterson (1940). More and more research is being conducted today as surgical operations have become commonplace (e.g. Spadliński et al. 2016).
New population-level data have therefore been available since the second half of the 20th century, indicating that cervical ribs are observed in up to $3 \%$ of the adult samples, depending on the population and the methodology used (Table 1).

Clinical case studies also distinguish three types of cervical ribs in adults (Figure 1). The first, 'rudimentary' or 'atrophied', type has the most restricted development. It may have either a proximal articular facet associated with the transverse process, or two proximal articular facets, one associated with the body of the vertebra and the other with the transverse process. A second undeveloped morphological type is called 'phalanx-like' in the English medical literature (Patterson, 1940). These ribs, several centimetres long, have a proximal articular facet associated with the transverse process, and a distal end that tapers off. The third type is the 'rib-shaped' cervical rib, which is larger than both previous types and strongly resembles a first rib, with two proximal articular facets. Intra-individual morphological diversity does exist for bilateral cervical ribs, since left and right ribs may be similar in shape and size or, conversely, may have extremely different morphologies (Patterson, 1940).

\begin{tabular}{|c|c|c|c|}
\hline Study & Type of sample & $n / N$ & Frequency ${ }^{\mathrm{a}}, \%$ \\
\hline Steiner, 1943 & Radiographs & 19/38 105 & 0.1 \\
\hline Etter, 1944 & Radiographs & 40000 & 0.2 \\
\hline Pionnier and Depraz, 1956 & Radiographs & 10000 & 0.5 \\
\hline Singh, 1973 & Radiographs & 9439 & 0.7 \\
\hline Palma and Carini, 1990 & Radiographs & 724 & 2.5 \\
\hline Brewin et al. 2009 & Radiographs & $710 / 1352$ & 0.7 \\
\hline \multicolumn{4}{|c|}{ Galis et al. 2006 analysis of existing dataset } \\
\hline Topinard, 1877 & Dried skeletons & $2 / 350$ & 0.6 \\
\hline Paterson, 1893 & Dried skeletons & $0 / 132$ & 0 \\
\hline Bianchi, 1894 & Dried skeletons & $0 / 130$ & 0 \\
\hline Staderini, 1894 & Dried skeletons & $1 / 100$ & 1 \\
\hline Fischel, 1906 & Dried skeletons & $5 / 524$ & 1 \\
\hline Henderson, 1914 & Radiographs & $31 / 80000$ & 0 \\
\hline Southam and Bythell, 1924 & Dried skeletons & $9 / 2000$ & 0.5 \\
\hline Steiner, 1943 & Radiographs & 19/38 105 & 0.1 \\
\hline Berner, 1944 & Radiographs & $9182 / 4333200$ & 0.2 \\
\hline Sycamore, 1944 & Dried skeletons & $10 / 2000$ & 0.5 \\
\hline Lanier, 1944 & Dried skeletons & $6 / 559$ & 1.1 \\
\hline Crimm, 1952 & Radiographs & $68 / 40000$ & 0.2 \\
\hline Crimm, 1952 & Radiographs & $116 / 71877$ & 0.2 \\
\hline Bokhari et al. 2012 & Radiographs & $34 / 1000$ & 3.4 \\
\hline Verna, 2014 & Medical scan & $21 / 999$ & 2.1 \\
\hline Bhat et al. 2015 & Radiographs & $50 / 1871$ & 2.7 \\
\hline Dharmshaktu and Bhandari, 2016 & Radiographs & $12 / 1500$ & 0.8 \\
\hline Davran et al. 2017 & CT scan & $19 / 560$ & 3.4 \\
\hline Agarwal et al. 2018 & Radiographs & $63 / 8000$ & 0.8 \\
\hline
\end{tabular}

TABLE 1 Overview of the frequency of cervical ribs in different contemporary study samples of adults with 100 or more individuals

Abbreviations: $\mathrm{CT}$, computed tomography; $\mathrm{n} / \mathrm{N}$, number of individuals with cervical ribs/number of individuals in the sample.

${ }^{a}$ Frequency of cervical ribs in the sample. 


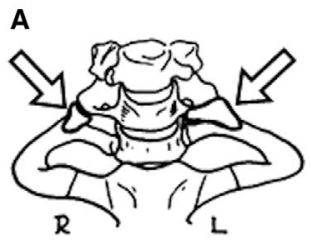

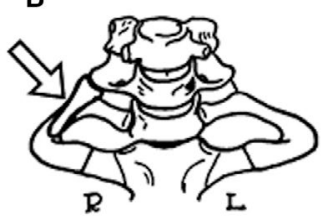

C

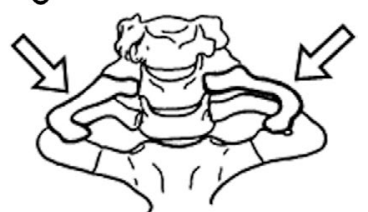

FIGURE 1 Morphological types of adult cervical ribs usually distinguished based on clinical studies. (A) 'rudimentary' or 'atrophied' type, (B) 'phalanx-like' type, (C) 'rib-shaped' type, modified after Patterson (1940, pp. 534-535, figures 4, 6 and 21)

Despite very good knowledge of the frequencies and morphology of cervical ribs in extant adult samples, little is known about their development in the early stages of life and in past populations. The documentation of cervical ribs in young immature specimens is indeed affected by ethical as well as technical limitations. Unlike adults, the occurrence of cervical ribs in young children very rarely leads to medical consultation, and recent studies have mostly been carried out on postmortem examination. Studying individuals who died at an early age raises additional ethical considerations. When ethical requirements allow the implementation of a study, it is carried out retrospectively on the basis of radiographic or computed tomography scanning examinations. The resolution of these images allows frequency data to be acquired, but is not sufficient to document the morphological variability of the cervical ribs accurately; this remains undocumented in neonates and infants. Furthermore, the available data also only describe modern populations. Some individual case studies of cervical ribs in the archaeological record have been published (Denninger, 1931; Drupka et al. 2019), but no archaeological collection has been comprehensively assessed for cervical rib frequencies up until now. The excavation of the Classic Kerma necropolis 8B-51 on Saï Island (Sudan), however, led to the discovery of many individuals who died at a very young age, many of them with cervical ribs (Murail et al. 2004; Murail and Geus, 2006). In the present study, we focused on this archaeological collection (a) to investigate the gap between the very high frequencies observed in this past population and those observed in contemporary collections, in order to propose the potentially simplest explanation for such a biologically uncommon trait expression in this Kerma group, and (b) to document the morphological variability of cervical ribs in human early life.

\section{2 | MATERIAL AND METHODS}

\section{1 | Study sample}

The study sample comes from the 8B-51 necropolis located on the Saï Island (Sudan), on the Nile, $100 \mathrm{~km}$ north of the third cataract (Geus, 2000). The site is located near the eastern shore of the island, to the northeast of the sandstone eminence named Gebel Adu, and covers $150 \mathrm{~m}^{2}$ (Figure 2).

A total of 66 individuals, 64 immature individuals and two adults, were exhumed using the techniques recommended by Duday et al. (1990) and Duday (2009). It was dated to the Classic Kerma period [grave 1:1582 \pm 40 cal BP; grave 10:1570 \pm 35 cal BP; grave $32: 1633 \pm 42$ cal BP; grave 66:1685 \pm 38 cal BP, based on C14 dating of the material (Murail et al. 2004; Murail and Geus, 2006)]. Only the immature individuals are analyzed in the present biological study (Partiot, 2018), which includes the acquisition of metric data and the estimation of age at death. We also searched for osteological anomalies, such as axial dysplasia (cranial malformations, sagittal clefts of the vertebrae, transitional vertebra in individuals whose vertebral sequence was fully preserved, lumbar ribs, bifid ribs, rudimentary 12th ribs, costal fusions), appendicular dysplasia (abnormal bowing or shortening of the limbs, radio-ulnar fusion) and changes suggestive of potential metabolic disorders (Lewis, 2017).

Ages at death of the immature individuals were estimated in weeks of amenorrhoea based on the length of long bones. The method of Fazekas and Kósa (1978), revised by Sellier (Schmitt and Georges, 2008), was selected because it is applicable to seven long bones and to fetuses and children up to 4 years of age, and has confidence intervals (Sellier et al. 1997). The method of Adalian et al. (2002), although developed on a large reference collection, could not be used because it only applies to the femur, and only to individuals with < 41 completed weeks of amenorrhea (CWA).

The sample includes 54 children who died during the perinatal period lato sensu (between 24 to 48 CWA, i.e. approximately 2 months postpartum, according to the definition chosen in this study), five children aged between 49 CWA and 1 year, and five children aged between 1 and 2 years. This very particular age profile of the necropolis population indicates that the site is dedicated to newborns and very young children (Murail et al. 2004; Murail and Geus, 2006). In order to improve analysis accuracy for the sample of individuals deceased at 24-48 CWA, we determined sub-age groups distinguishing the highly premature individuals who died at 24-34 CWA ( $n=3$ ), the slightly premature individuals who died at 35-37 CWA ( $n=2)$, the full-term individuals whose age-at-death confidence intervals included the theoretical term of 40 CWA ( $n=32$ ), and the newborns who died at 41-48 CWA ( $n=17)$. All of the above form the group of individuals deceased during the perinatal period.

\subsection{The cervical ribs}

The individuals were buried in an ancient Nile Valley alluvial formation, very rich with small gravels and sands and very fine sediments such as Nile silts. All the graves are primary individual graves in the ground, with the exception of two possible double graves and one possible secondary burial (Leclerc, 1990; Duday, 2009). The climate, 
A
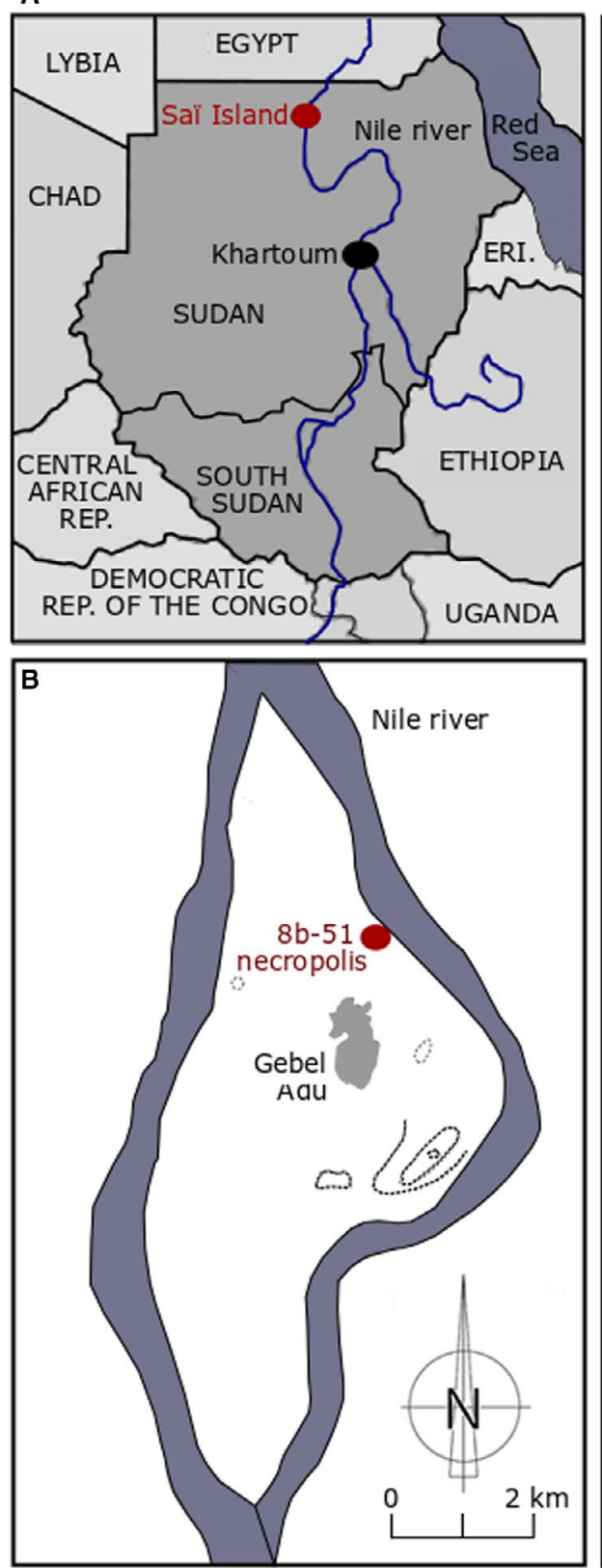

c

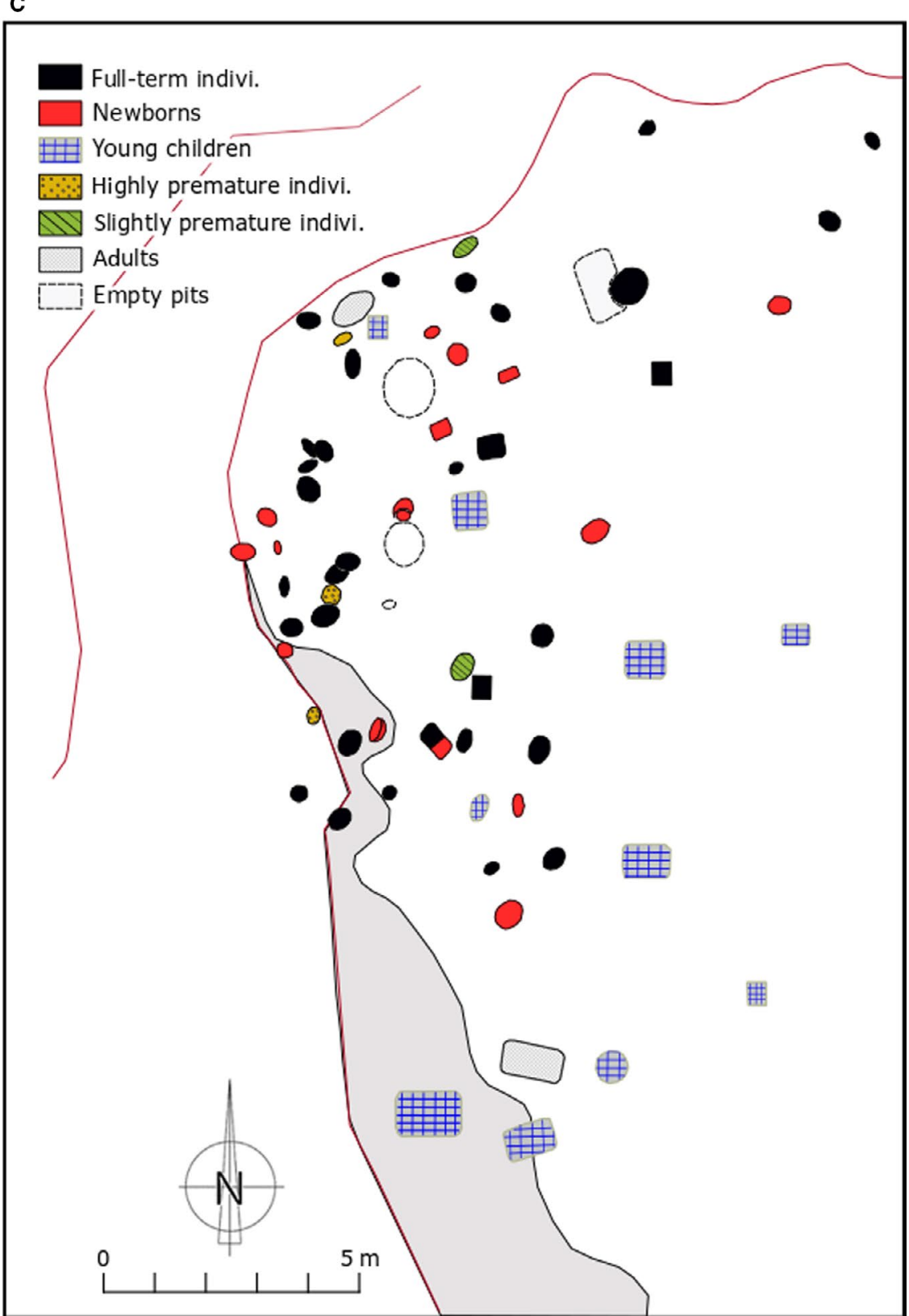

FIGURE 2 Location of the necropolis on the (A) Sudan scale and (B) Saï Island scale, and (C) map of the location of burials according to the age at death of the individuals, modified after Murail et al. (2004, pp. 268-269, Figures 1 and 2)

the 'nature' of the substratum, natural mummification and funeral practices (Maureille and Sellier, 1996) have preserved most of the anatomical connections of the buried individuals, with the exception of several disturbances by looting of two burials (S22 and S68). In some cases, the sediments filled the spaces left by the decomposition of the corpse. This specific context and a precise excavation project, led by physical anthropologists, as well as chance (the first adult specimen excavated presented cervical ribs), have favoured the discovery of such small bone elements, including the neonate cervical ribs (Figure 3).

The cervical ribs were identified near the hemi-arch of the seventh cervical vertebrae. Their bilateral or unilateral occurrence was noted in situ for each individual in the sample. Most of the individuals were buried on their backs, which facilitated the lateralization of these very small elements. For some poorly preserved burials or for individuals buried on their side, the supernumerary ribs could not be lateralized with certainty. Owing to the difficulty in distinguishing between the upper and lower surfaces on some very small elements, it was not possible to lateralize them retrospectively. A pair of cervical ribs on a highly premature individual (individual S3) was removed but broke during an attempted consolidation process using a mixture of white glue and acetone. These elements were included in the frequency count and in the morphological analysis, but not in the metrical analysis. Maximum length, maximum width and minimum width of each intact cervical rib were then measured with an electronic caliper (precision: 1/10 mm; Figure 4).

Correlation between the estimated age at death in CWA and the maximum length of the cervical ribs was analyzed using a Pearson 
FIGURE 3 In situ identification of the cervical ribs, examples. (A) Right cervical rib of the individual S56, (B) bilateral cervical ribs of the individual S11, (C) right cervical rib of the individual S58, and (D) left cervical rib of the individual S71


FIGURE 4 Illustration of the measurements acquired during the biological study on the right cervical rib of the individual S60. L, maximum length; Min W, minimum width; Max W, maximum width
L

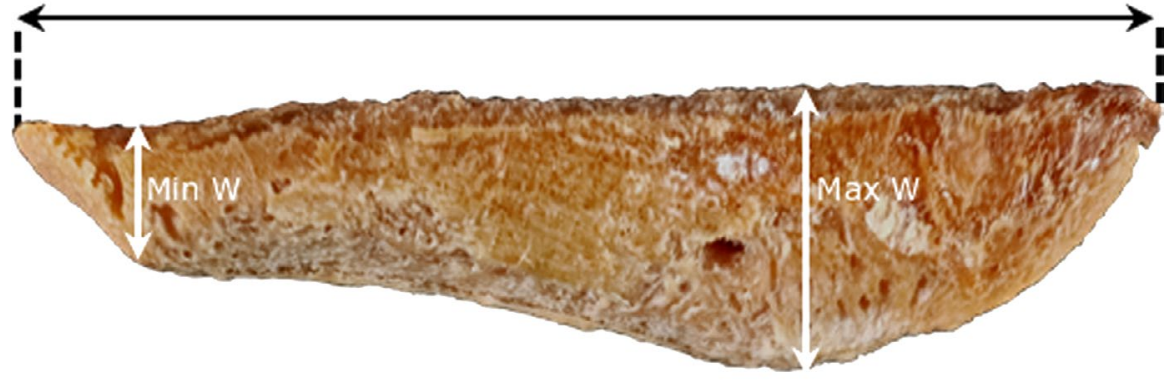

0

$5 \mathrm{~mm}$

linear correlation test. In the case of bilateral cervical ribs, only the longest one was conventionally included in the sample tested. Age at death was treated as a continuous variable. All analyses were conducted in the free software $\mathrm{R}^{*}($ version 3.3., R Core Team, 2017).

\section{RESULTS}

\subsection{General frequencies}

Cervical ribs were identified in the field in 28 of the 64 individuals, for a total of 45 ribs. An individual (S22) who died aged between 1 and 2 years, identified in the field with bilateral cervical ribs, was then excluded from the sample during the laboratory study. His/her spine had been severely disrupted by looting, which made the position of the ribs uncertain, especially since they looked much more like supernumerary lumbar ribs. According to the laboratory study, at least 27 of the 64 immature individuals had unilateral or bilateral cervical ribs, which corresponds to a frequency of $42 \%$. Among the 54 individuals deceased during the perinatal period, 24 had this anatomical variant, which corresponds to a frequency of $44 \%$ in the subgroup (Table 2 ).

These are minimum frequencies and can therefore only be equal to or lower than the actual frequency, since some ribs may not have been preserved or found (there was no water sieving), or may have been broken during the excavation. A total of 43 cervical ribs were therefore identified. They were mainly observed bilaterally $(n=16$ individuals, i.e. $59 \%$ of the sample with cervical ribs). This is again a minimum frequency, since unilateral ribs could have been initially bilateral, before one was either missed in excavation or destroyed. For unilateral ribs ( $n=11$ individuals, $41 \%$ of the sample with cervical ribs), cervical ribs appeared to be more frequent on the right side $(n=4)$ compared to the left side $(n=1)$, but this observation must be balanced by the large number of ribs with an undetermined side $(n=6)$. 


\section{2 | Metrical and morphological variability}

\subsection{1 | General description}

Of the 43 cervical ribs identified, 32 (30 preserved and the two that were broken during consolidation) could be taken into consideration for the morphological study. Each had an expanded lateral head that could be rounded or more angular, and a smaller medial end, both with one well-defined articular facet (Figure 5).

The lateral articular facet was the largest and could appear more or less curved, flat or depressed. The medial articular facet was more or less inclined and its extent could vary. These articular facets on both ends allowed us to distinguish the cervical ribs from a hyoid long horn.
The shaft of the cervical rib could be straight, bent or slightly twisted. The medio-posterior border of the shaft could be sharper than the antero-lateral one, which could be more rounded. The surfaces of the shafts showed both compact bone and pitting areas, indicating significant vascularization and active bone formation processes. There were no corresponding articular facets on the vertebral hemi-arches. Within the sample, no morphological difference was identified between the vertebral hemi-arches of individuals with cervical ribs and vertebral hemi-arches of individuals without cervical ribs.

Maximum length was preserved for 30 cervical ribs, maximum width for 32 and minimum width for 31 (Supporting information). The maximum length of all the cervical ribs ranged between $5.5 \mathrm{~mm}$ (individual S12-1, full-term individual), and $10.3 \mathrm{~mm}$ (individual $\mathrm{S} 8$,

\begin{tabular}{|c|c|c|c|c|c|c|c|}
\hline \multirow[b]{3}{*}{ Age groups } & \multirow[b]{3}{*}{$N$} & \multicolumn{6}{|c|}{ Number with cervical ribs } \\
\hline & & \multirow[b]{2}{*}{ Total } & \multirow[b]{2}{*}{ NB } & \multicolumn{4}{|l|}{ NU } \\
\hline & & & & Total & NUL & NUR & NUU \\
\hline \multicolumn{8}{|l|}{ Perinatal period } \\
\hline Highly premature individuals & 3 & 2 & 2 & 0 & 0 & 0 & 0 \\
\hline $\begin{array}{l}\text { Slightly premature } \\
\text { individuals }\end{array}$ & 2 & 1 & 1 & 0 & 0 & 0 & 0 \\
\hline Full-term individuals & 32 & 12 & 7 & 5 & 0 & 2 & 3 \\
\hline Newborns & 17 & 9 & 6 & 3 & 0 & 1 & 2 \\
\hline From 49 CWA to 1 year of age & 5 & 3 & 0 & 3 & 1 & 1 & 1 \\
\hline From 1 to 2 years of age & 5 & 0 & 0 & 0 & 0 & 0 & 0 \\
\hline Total & 64 & 27 & 16 & 11 & 1 & 4 & 6 \\
\hline
\end{tabular}

Abbreviations: $\mathrm{N}$, number of individuals in each age group; NB, number of individuals with bilateral ribs; NU, number of individuals with unilateral ribs; NUL, number of individuals with unilateral left rib; NUR, number of individuals with unilateral right rib; NUU, number of individuals with unilateral ribs of undetermined side.
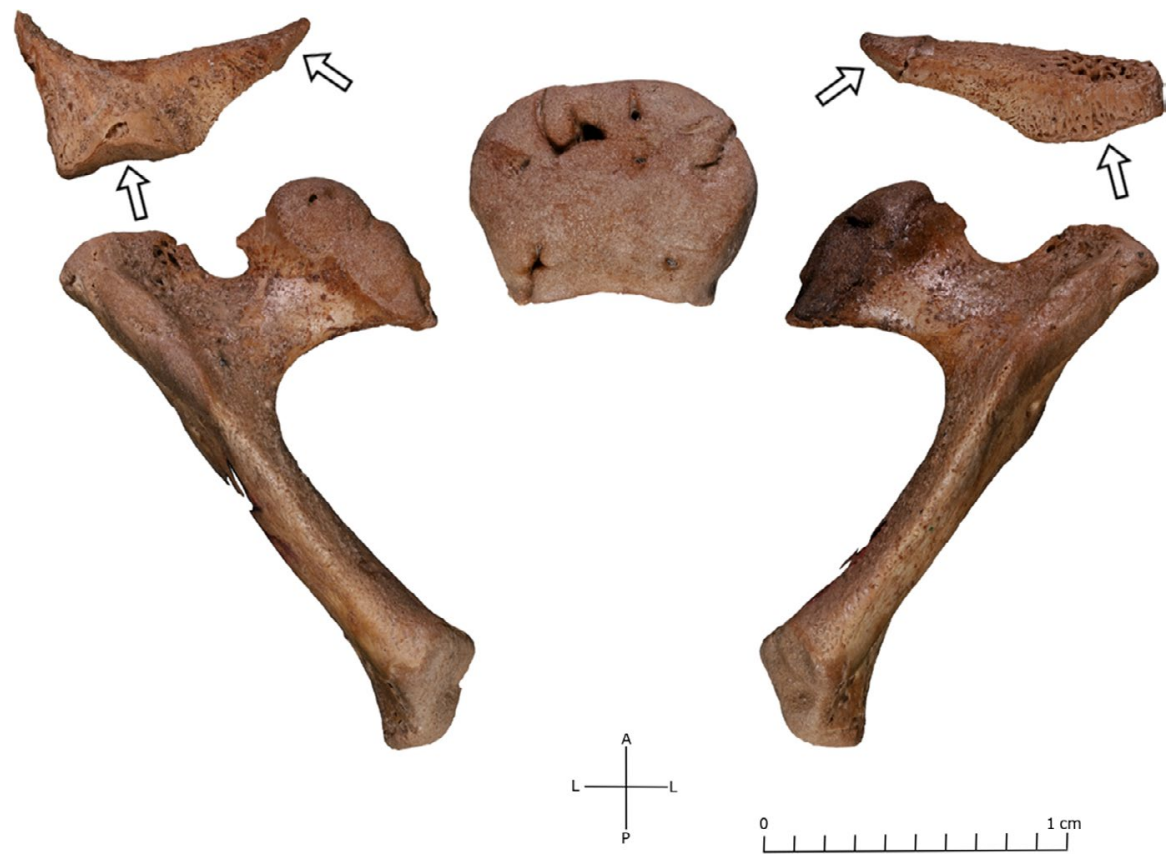

TABLE 2 Distribution of the cervical ribs between age groups in the immature sample of Saï
FIGURE 5 Repositioning with orientation of the cervical rib in relation to the vertebral hemi-arches and the vertebral centrum, example of the individual S11. Arrows, articular surfaces; $A$, anterior; $L$, lateral; $P$, posterior 
deceased between 49 CWA and 1 year). The average maximum length of the ribs was $7.4 \mathrm{~mm}$, the average maximum width was $2.1 \mathrm{~mm}$, and the average minimum width was $1.1 \mathrm{~mm}$. The results of correlation analysis showed a statistically significant and positive correlation between the estimated age at death and the length of the elements for the entire sample, including the ribs belonging to the oldest individuals ( $P$ value $=0.002$ ), but not among individuals deceased during the perinatal period.

\subsection{2 | Morphological variability: classification proposition}

As in adults, an important morphological range of variation for cervical ribs does exist during early childhood, making it possible to propose the first classification system for these age groups. It is based on the 30 preserved cervical ribs and on the two that were broken during the consolidation attempt, elaborated according to two criteria: (1) the general shape of the rib and (2) the shape of the posterior articular facet. Four types are proposed (Figure 6) and are described below.

A-type. The A-type has a linear or slightly curved shaft, with the posterior articular facet curved or flat. The maximum length of the ribs belonging to the A-type range between 5.5 and $10.3 \mathrm{~mm}$, with an average maximum length of $7.3 \mathrm{~mm}$. It is represented by 28 elements out of the 34 observable ribs (82\%).

B-type. The B-type has discontinuous profile characterized by a posterior notched or depressed articular facet. The maximum length of the ribs belonging to the B-type ranges between 7 and $8.3 \mathrm{~mm}$, with an average length of $7.6 \mathrm{~mm}$. Type $B$ is represented by three elements out of the 34 observable ribs (i.e. $9 \%$ of the corpus).
C-type. The C-type has a non-linear shape, with a large posterior articular facet and a lateral 'horn-like' bone extension. One C-type rib is preserved on a newborn (individual S11, maximum length of $10 \mathrm{~mm}$ ), and two are broken on a highly premature individual, which corresponds to a total frequency of $9 \%$ of the corpus.

\subsection{3 | Intra-individual diversity}

For bilateral cervical ribs, the left and right elements have an average difference of $0.6 \mathrm{~mm}$ in maximum length, of $0.4 \mathrm{~mm}$ in maximum width and $0.3 \mathrm{~mm}$ in minimum width (Supporting information). For the 12 individuals with bilateral observable cervical ribs, right and left ribs belong in most cases to the same morphological type ( $n=11 / 12$ ). Differences were seen only for one individual (S11), for which the right one belonged to A-type, and the left to C-type.

\section{4 | DISCUSSION}

\section{1 | High frequency of cervical ribs}

According to our results, the frequencies of cervical ribs in the archaeological corpus are extremely high compared to those observed in contemporary adult populations (Table 1). This discrepancy can be investigated through several hypotheses. The first hypothesis (H1) is that the frequencies of the variant observed in adulthood would be lower because the cervical ribs would in most cases fuse during childhood with the transverse process of the vertebral hemiarch. The second hypothesis $(\mathrm{H} 2)$ is based on a presumed genetic origin and heritability of the variation (Barnes, 1994). If it was a

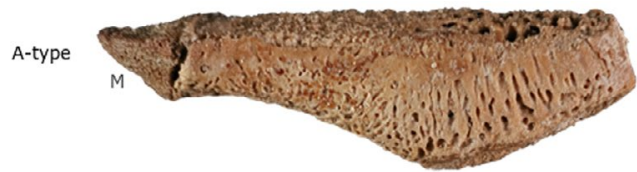

B-type
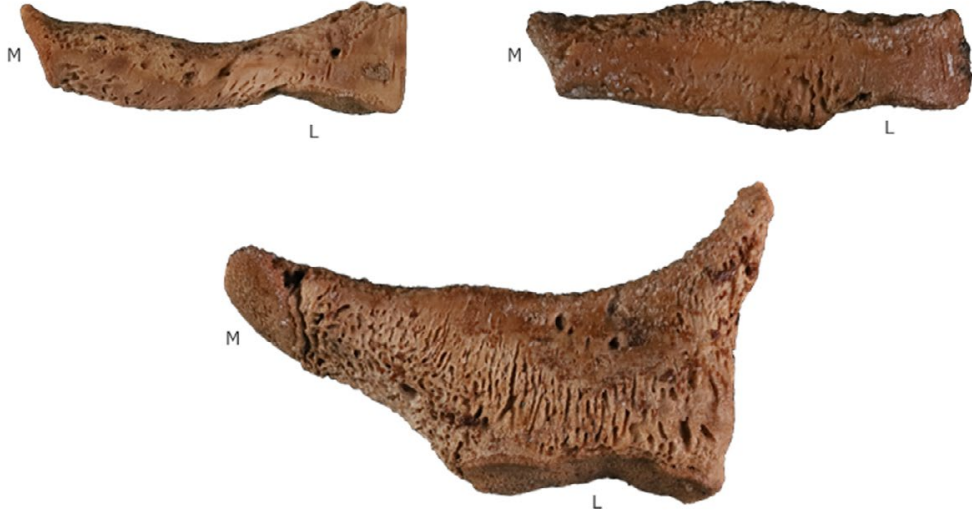

C-type

FIGURE 6 Morphological variability of cervical ribs in early life: classification proposition. Superior view. L, lateral articular surface; $\mathrm{M}$, medial articular surface. A-type: right cervical rib of the individual S11 and cervical rib of the individual S9. B-type: cervical ribs of the individual S70 and the individual S39. C-type: left cervical rib of the individual S11
.
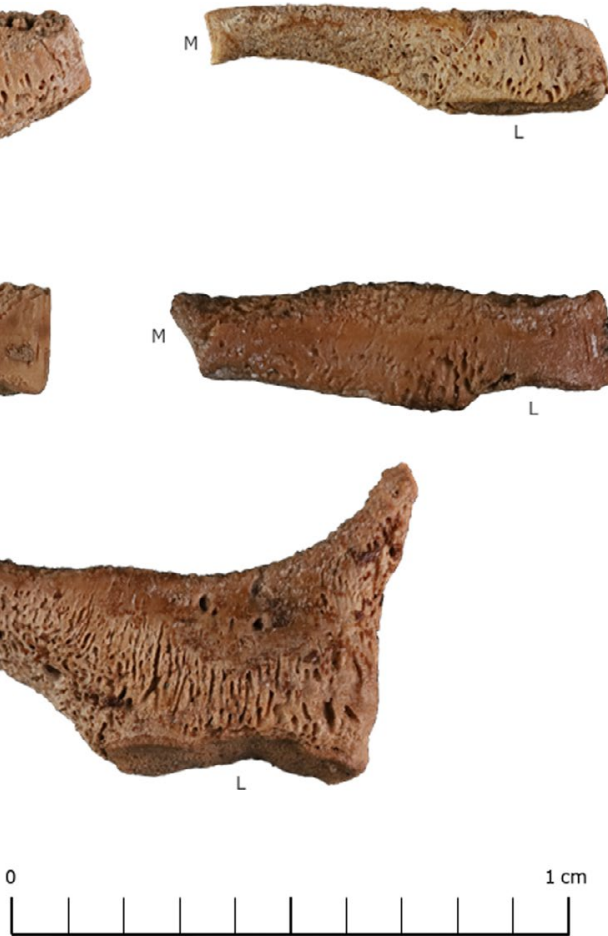
'population-based' characteristic, it could be highly prevalent within certain groups, even in early childhood. The third hypothesis $(\mathrm{H} 3)$ is that the immature individuals with cervical ribs would for the most part not be represented in the adult sample, since they would die before adulthood.

H 1 Fusion of the cervical rib with the transverse process of the vertebral hemi-arch

Many authors have supported the hypothesis that the cervical supernumerary rib may be a normal secondary ossification point occurring at around the 6th fetal month (Black and Scheuer, 1997). It would remain independent until the age of 4-10 years, when it merges with the transverse process of the hemi-arch on the seventh vertebra and form the anterior part of the transverse foramen (Todd, 1912; Gladstone and Wakeley, 1932; O'Rahilly and Gardner, 1975; McNally et al. 1990; O'Rahilly et al. 1990; Black and Scheuer, 1997; Chernoff and Rogers, 2004; Cunningham et al. 2016). As the element would no longer be identifiable in isolation among older individuals, the frequencies of cervical ribs in children would hence be overestimated under the age of 10 years (Black and Scheuer, 1997). Following this hypothesis, the fusing of cervical ribs with the transverse process of the 7th cervical vertebra could lead to a longer transverse process than those of the 1st thoracic vertebra, and may in some cases be identified as apophysomegaly.

However, this hypothesis has been recently debated in the scientific literature (Galis et al. 2006; Bots et al. 2011), since these elements should in that case be found mostly bilaterally in close to $100 \%$ of extant samples of individuals in early infancy, and at least very frequently in archaeological collections. However, this variant is observed in only one- to two-thirds of the extant samples of fetuses and infants, and unilaterally in a quarter to a third of the cases (e.g. Galis et al. 2006; Bots et al. 2011; Table 3), which is not consistent with this hypothesis.

\section{H 2 A 'population-based' characteristic}

The cervical rib is classically described as a hereditary trait (Thompson, 1910; Weston, 1956; Berry and Berry, 1967; Barnes, 1994; Black and Scheuer, 1997), and it is interesting to note that one of the only two adults of the site had one pair of cervical ribs. Even if the region has been continuously populated since the Paleolithic (Van Peer et al. 2003; Rots and Van Peer, 2006), the island environment could induce genetic homogeneity, or even endogamy, and contribute to higher frequencies of such anatomical traits. Furthermore, the fact that consanguinity leads to the expectation of an increased incidence of cervical ribs in humans (Palma and Carini, 1990) and other mammals (Van der Geer, \& Galis 2017) was highlighted in the literature. As the origin of the sample of Palma and Carini (1990) is unclear, but the radiographs may have been taken on patients, it is, however, not clear to what extent the study sample is representative of the general population, and to what extent the incidence of cervical ribs is related to the isolation of the population itself.

Nevertheless, many studies carried out on contemporary non-consanguineous collections of immature individuals have shown very high frequencies of cervical ribs (between $19 \%$ and $63 \%$; Table 3)

In these large extant samples (between 199 and 1000 individuals), the possibility of endogamy cannot be taken into account, which means that this factor is not sufficient to explain the frequency

TABLE 3 Overview of the frequency of cervical ribs in contemporary samples of dead or diseased children

\begin{tabular}{|c|c|c|c|c|}
\hline References & Description of the sample & Type of sample & $N$ & Frequency $^{\mathrm{a}}, \%$ \\
\hline Bagnall et al. 1984 & $\begin{array}{l}\text { Fetuses ranging in gestational age from } 8 \text { to } 26 \text { weeks, } \\
\text { spontaneous abortions and hysterectomies. }\end{array}$ & Radiographs & 728 & 19 \\
\hline McNally et al. 1990 & $\begin{array}{l}\text { Stillborn fetuses presented for autopsy ( } 14 \text { gestational weeks } \\
\text { to } 42 \text { gestational weeks) deceased in Northwick Park Hospital } \\
\text { (Harrow, UK) between } 1972 \text { and } 1988 .\end{array}$ & Radiographs & 715 & 63 \\
\hline $\begin{array}{l}\text { Schumacher et al. } \\
1992\end{array}$ & Individuals with malignancies up to 21 years old. & Radiographs & 1000 & 21.8 \\
\hline Galis et al. 2006 & $\begin{array}{l}\text { Fetuses and infants presented for autopsy between } 1992 \\
\text { and } 1999 \text { in the Free University Medical Centre (VUMC) in } \\
\text { Amsterdam, including medical abortions. }\end{array}$ & Radiographs & 598 & 55 \\
\hline Bots et al. 2011 & $\begin{array}{l}\text { Electively aborted fetuses collected at the Institute of Dentistry, } \\
\text { University of Turku (Finland) between } 1965 \text { and } 1975 .\end{array}$ & $\begin{array}{l}\text { Treated with potassium } \\
\text { hydroxide and alizarin red }\end{array}$ & 199 & 37.7 \\
\hline Furtado et al. 2011 & $\begin{array}{l}225 \text { stillborns (> } 20 \text { weeks old) and } 93 \text { deceased live-born } \\
\text { infants (< } 1 \text { year old). }\end{array}$ & Radiographs & 225 & 43.1 \\
\hline Schut et al. 2019b & $\begin{array}{l}\text { 'Fetuses and infants, younger than } 1 \text { year old, deceased } \\
\text { between } 2009 \text { and } 2015 \text { in the Erasmus University Medical } \\
\text { Centre Sophia Children's Hospital, for whom a babygram, } \\
\text { autopsy report and/or SNP Array was available' }\end{array}$ & Radiographs & 374 & 50.3 \\
\hline
\end{tabular}

Note: $N$, number of individuals in the sample.

${ }^{a}$ Frequency of cervical ribs in the sample. 
differences between the Saï corpus and the contemporary adult corpuses (Table 1).

\section{H 3 The cervical rib during early childhood, a 'morbidity criterion'}

A third hypothesis can be put forward considering the nature of the immature samples with high frequencies of cervical ribs. With the exception of Schumacher et al. (1992), whose sample includes individuals indicated with cancer, all studies presented above (Table 3) were indeed conducted on samples of deceased individuals (fetuses or infants), which are non-representative of the theoretical natural population that would include surviving and non-surviving individuals (Bots et al. 2011).

Other studies carried out on a sample closer to a natural population, such as random or routine medical examinations (Table 4), show cervical rib frequencies ranging between $0.5 \%$ and $5.5 \%$, which is consistent with the range of variation observed in adult populations, i.e. between $0.3 \%$ and $3 \%$ (Table 1 ).

Cervical ribs therefore appear to be much more frequent in diseased samples than in samples close to a natural population. Considering this observation, the hypothesis can be made that the presence of the cervical rib may cause medical problems, compromising the individual's health, such as those that can be observed in adults. In adolescents, changes in surrounding tissues similar to those observed in adults are sometimes identified (e.g. Vercellio et al. 2003; Grier et al. 2008). To our knowledge, the presence of a cervical rib in a newborn is only known to cause brachial plexus paralysis, when the rib mechanically damages nerve structures during delivery (Tzou, Paternostro-Sluga, Frey, \& Aszmann, 2014a, 2014b; Lewis, 2017). The consequences of this damage are disabling to a greater or lesser extent depending on the extent of the injury, but do not jeopardize the survival of the individual (Tzou, PaternostroSluga, Frey, \& Aszmann, 2014a, 2014b).

Recent biological and genetic studies, however, indicate that the cervical rib in early childhood is identified, in mice and in humans, as positively and significantly associated with the most frequent congenital anomalies, and several severe medical conditions [Table 5
(Adson \& Coffey 1927; Gladstone and Wakeley, 1932; Bagnall et al. 1984; McNally et al. 1990; Schumacher et al. 1992; Keeling and Kjaer, 1999; Galis et al. 2006; Bots et al. 2011; Castori et al. 2016, Schut et al. 2019a; 2019b)].

Its presence is caused by early developmental disruption with altered expression of Hox genes, which play an important role in the formation of the axial skeleton (Krumlauf, 1994), and might be responsible for the thoracification of the seventh cervical vertebrae, i.e. its partial or complete homeotic transformation into the thoracic vertebra by the occurrence of one or two cervical ribs (Galis, 1999; Galis et al. 2006; Bots et al. 2011). At least four mutations of Hox genes (Hoxa-4, Hoxd-4, Hoxa-5 and Hoxa-6) have been identified in mice as responsible for the occurrence of this variation (synthesis in Horan et al. 1995). As these mutations also have an impact on organogenesis, it results in the occurrence of anomalies that greatly reduce fitness in mammals (Galis, 1999).

As a consequence, in the sample of Galis et al. (2006), at least $78 \%$ of fetuses with cervical ribs died before birth, and $83 \%$ before reaching the age of 1 year. The authors point out that in comparison, only $9 \%$ of the individuals without cervical ribs in the sample died before this age. Having cervical ribs during early life might lead to a significantly reduced chance of survival to adulthood, and this variant may therefore be considered as an indicator of a highly compromised health status, i.e. a morbidity criterion (Anbazhagan and Raman, 1997; Galis, 1999; Galis et al. 2006; Bots et al. 2011).

\section{2 | Morphological and intra-individual variability}

Our results indicate that the maximum length of cervical ribs increases in infants as growth progresses; however, as the correlation is not significant among the individuals who died during the perinatal period, other factors, such as individual variability, seem to remain predominant in this subgroup.

In terms of the general morphological variability, the link between the morphologies observed around birth (Figure 6) and those

TAB LE 4 Overview of the frequency of cervical ribs in contemporary samples of children from random medical examination

\begin{tabular}{|c|c|c|c|c|}
\hline Study & Composition of the sample & Type of sample & $N$ & Frequency $^{\mathrm{a}}, \%$ \\
\hline Hershkovitz, 2008 & $\begin{array}{l}\text { Prospective study of low-risk } \\
\text { women with singleton pregnancy } \\
\text { and normal fetal anatomy scan }\end{array}$ & $\begin{array}{l}\text { 3D examinations of the fetal ribs were } \\
\text { carried out at the time of the routine } \\
\text { anomaly scan at } 14-16 \text { or } 20-24 \text { weeks of } \\
\text { gestation }\end{array}$ & $5 / 367$ & 1.4 \\
\hline $\begin{array}{l}\text { Davis and King, } 1938 \text { cited by } \\
\text { Bots et al. } 2011\end{array}$ & $\begin{array}{l}\text { Children aged }<13 \text { years, hospital } \\
\text { database }\end{array}$ & Radiographs & 1000 & 1.2 \\
\hline Naik et al. 1978 & $\begin{array}{l}\text { Myelomeningoceles patients who } \\
\text { died before } 1 \text { year of age }\end{array}$ & Radiographs & 112 & 4.5 \\
\hline Schumacher et al. 1992 & $\begin{array}{l}\text { Infectious disease patients aged } \\
\text { between } 15 \text { months and } 14 \text { years }\end{array}$ & Radiographs & $9 / 200$ & 4.5 \\
\hline $\begin{array}{l}\text { Carretero and Campo Munoz, } \\
1967\end{array}$ & $\begin{array}{l}\text { Healthy female immature individuals, } \\
\text { relatives of tuberculosis patients. }\end{array}$ & Radiographs & 25949 & 0.5 \\
\hline
\end{tabular}

Note: $N$, number of individuals in the sample.

${ }^{a}$ Frequency of cervical ribs in the sample. 
TAB LE 5 Overview of the frequency of cervical ribs in relation to developmental abnormalities in contemporary samples with 30 individuals or more

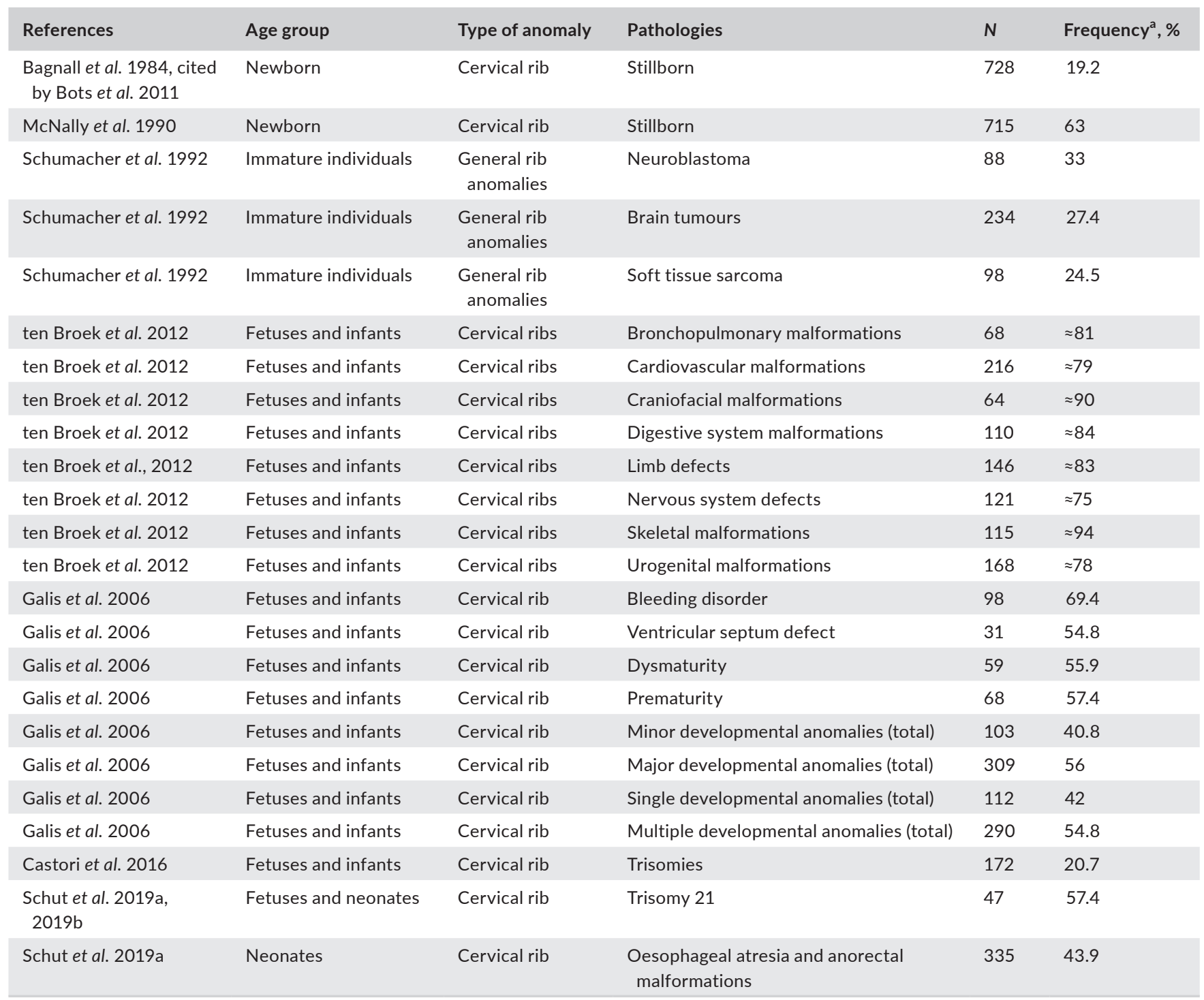

Note: $\mathrm{N}$, number of individuals in the sample.

${ }^{\mathrm{a}}$ Frequency of cervical ribs or general rib anomalies in the sample; $\approx$ : frequency after the Figure 5 of ten Broek et al. (2012)

observed in adults in the medical literature (Figure 1) should also be discussed. It is possible to hypothesize that small cervical ribs, such as those of A- or B-type, could evolve into adult rudimentary or 'phalanx-like' cervical ribs. C-type cervical ribs could prefigure more developed supernumerary ribs in adulthood, such as 'rib-shaped' ribs. If the rudimentary rib frequencies observed in adults were close to the frequencies of A- and B-type cervical ribs in infants, it could be an argument in favour of this hypothesis. However, the results of the study by Sanders and Hammond (2002) showed a different distribution in their corpus of 40 adults. Small or 'rudimentary' ribs (1-2 $\mathrm{cm}$ ) are observed in $27.5 \%(n=11 / 40)$ of the sample, 'phalanx-like' ribs $(2-5 \mathrm{~cm})$ in $42.5 \%(n=17 / 40)$ and complete of 'rib-shaped' ribs in $30 \%$ ( $n=12 / 40)$.

Regarding intra-individual diversity, cervical ribs in the archaeological sample are more frequently bilateral ( $61 \%$ of the sample) than unilateral (Table 2). The same results were found in clinical studies performed on fetuses and deceased newborn, with bilateral cervical ribs observed in $70.7 \%$ of the elective abortions sample of Galis et al. (2006), and in 73\% of the stillborn sample of McNally et al. (1990). The frequencies observed in the archaeological sample therefore appear to be consistent with the results of these clinical studies in early infancy, particularly considering that they are minimum. However, no comparison can be made with clinical research studies in adult contemporary samples, as cervical ribs are alternately indicated to occur mostly bilaterally (e.g. Savgaonkar et al. 2006; Gupta et al. 2012; Verna, 2014), or mostly unilaterally (e.g. Sharma et al. 2014; Bhat et al. 2015).

For unilateral ribs in modern corpuses of infants, the predominant side varies also according to the samples. The left cervical rib is more frequent $(17.3 \%$ vs. $12 \%$ on the right side) in the sample of Galis et al. 
(2006), but less frequent in the sample of McNally et al. (1990) (11\% on the left side and $16 \%$ on the right side). Considering bilateral cervical ribs, our results highlight the relatively low intra-individual variability during early childhood. Only one individual had very different right and left cervical ribs. Although no frequency data are available, cases of asymmetries appear, on the contrary, to be more frequent, for example, among the adult clinical cases of Patterson (1940).

With regard to morphological and intra-individual diversity, longitudinal studies are needed to identify which shape observed in immature individuals may develop into a shape observed in older individuals. The hypothesis that there may be two different types of cervical ribs, one associated with developmental abnormalities, and the other more likely to develop as an adult supernumerary rib, should also be taken into consideration based on clinical studies.

\section{3 | Conclusions for the 8B-51 Classic Kerma collection}

The frequencies of cervical ribs in the archaeological sample are of the same order as those observed in collections of individuals with compromised health status (Table 3 ). With regard to studies demonstrating the link between their occurrence and a reduced chance of survival, these results allow a first identification of the cervical ribs as an indicator of morbidity in a human past population. Although the high frequency of cervical ribs may reflect a generally compromised health status, this has not been identified from the biological study of the sample, as we did not detect on dry bone the presence of developmental abnormalities. Of the spinal variations analyzed, only one lumbar supernumerary rib could be identified. Since ribs were only measured when all 12 ribs were preserved and positively identified, the rudimentary 12th rib (i.e. smaller than half the length of the 11th rib) was searched for in only four individuals. None of them appeared to show this variation, which appears to be particularly associated with developmental disorders (ten Broek et al. 2012). However, even if it has been suggested that vertebral homeotic transformations are frequent in individuals with cervical ribs (ten Broek et al. 2012), many disorders identified as being related to their presence occur only in soft tissue, not in the skeleton (Table 5). This absence of obvious bone abnormalities does not contradict the hypothesis supported by the high frequencies of cervical ribs.

Although the potentially isolated nature of the Saï population cannot be considered the major cause of these cervical rib frequencies, some influence of a genetic proximity or consanguinity has to be considered as a contributing factor. Regarding this hypothesis, the study of the trait in collections of adults from the same chrono-geographical context, including those from the Kerma necropolis (Simon, 1980; Bonnet et al. 1991), could be particularly relevant in the future.

As it is currently technically and ethically difficult to obtain accurate morphological information in modern samples, the new data on the morphological variability of the cervical ribs have to be compared with other archaeological collections. As this characteristic is frequently associated with childhood deaths, it should theoretically be commonly discovered in past populations, in which infant mortality was very high. On average, one in two children dies before the age of five before Jennerian vaccination (Ledermann, 1969). The fact that the 8B-51 sample is, to our knowledge, the first documented archaeological collection of cervical ribs in immature individuals would therefore appear to be unusual; however, two factors may explain this situation, the first being the fact that discoveries of series of immature individuals are in fact a recent phenomenon in itself. The children who died in their first years of life are regularly mentioned as under-represented in funerary sites (Blaizot et al. 2003; Lewis, 2007). Shallower dug graves than those of adults and more frequently disturbed graves may have limited the sample constitution. As such, the development of the principles of archaeothanatology (Duday et al. 1990; Duday and Guillon, 2006; Duday, 2009) has played and will continue to play a role in the constitution of the immature samples. The second factor explaining this lack of archaeological samples with cervical ribs is that this anatomical structure, being extremely small and fragile, may have been rarely preserved in the sediment or easily missed during the excavation of infant burials. Continued archaeological excavations with increased attention to this feature, particularly in sandy sedimentary environments, could therefore improve knowledge of anatomical variability in infants and young children.

\section{ACKNOWLEDGEMENTS}

We would like to thank the Sudan Antiquities Service and the French Section of the Sudan Antiquities Directorate for their help and support, as well as the French Ministry of Foreign Affairs, the CNRS UMR 5199 PACEA, and the University of Bordeaux. We also express our gratitude to the members of the Archaeological Mission of the Saï Island, Pascal Murail and the late Francis Geus, and to the Sudanese workers who participated in the excavation campaign. We thank Gregory Gay for his support in carrying out this study, as well as Kate McGrath and especially Trenton Holliday in proofreading the manuscript. Finally, we thank particularly the anonymous reviewers for providing useful comments on our paper.

\section{CONFLICT OF INTEREST}

None declared.

\section{DATA AVAILABILITY STATEMENT}

The remains are available for study on request at the CNRS UMR 5199 PACEA (Bâtiment B8, Allée Geoffroy Saint Hilaire, CS 50023 33615 PESSAC CEDEX France).

ORCID

Caroline Partiot (iD https://orcid.org/0000-0002-1466-7004

\section{REFERENCES}

Adalian, P., Piercecchi-Martia, M.D., Bourlière-Najeanc, B., Panuel, M., Leonetti, G. and Dutour, O. (2002) Nouvelle formule de détermination de l'âge d'un fœtus. Comptes Rendus Biologies, 325, 261-269. 
Adson, A.D. and Coffey, A.W. (1927) Cervical rib: a method of anterior approach for relief of symptoms by division of the scalenus anticus. Annals of Surgery, 85, 839-857.

Agarwal, S., Choudhury, P.R., Baro, A., Baruah, P. and Nath, D. (2018) Cervical ribs: a study on radiographs in a tertiary care hospital of Assam. International Journal of Anatomy and Research, 6, 4994-4998.

Anbazhagan, R. and Raman, V. (1997) Homeobox genes: molecular link between congenital anomalies and cancer. European Journal of Cancer, 33, 635-637.

Bagnall, K.M., Harris, P.F. and Jones, P.R.M. (1984) A radiographic study of variations of the human fetal spine. The Anatomical Record, 208 , 265-270.

Barnes, E. (1994) Developmental Defects of the Axial Skeleton. Niwot, CO: University Press of Colorado.

Berner, F. (1944) Über Rippenanomalien auf Grund von 6 Millionen Reihenbildern. Fortschr Geb Rontgenstrahlen, 69, 202-221.

Berry, A.C. and Berry, R. (1967) Epigenetic variation in the human cranium. Journal of Anatomy, 101, 361-379.

Bertelsen, S., Mathiesen, F.R. and Øhlenschlaeger, H.H. (1968) Vascular complications of cervical rib. Scandinavian Journal of Thoracic and Cardiovascular Surgery, 2, 133-139.

Bhat, M., Mir, T. and Abdullah, I. (2015) Prevalence of cervical ribs and elongated transverse processes in Kashmiri population. International Journal of Research in Medical Sciences, 3, 3763-3765.

Bianchi, S. (1894) Sulla frequenza della anomalie numeriche vertebrali nello scheletro dei normali e degli alienate. Atti Accad Fisiocrit Siena, 7, 21-31.

Black, S. and Scheuer, L. (1997) The ontogenic development of the cervical rib. International Journal of Osteoarchaeology, 7, 2-10.

Blaizot, F., Alix, G. and Ferber, E. (2003) Le traitement funéraire des enfants décédés avant un an dans l'Antiquité : Études de cas. Bulletins et mémoires de la Société d'anthropologie de Paris, 15, 49-77.

Bokhari, R.F., Al-Sayyad, M.J. and Baeesa, S.S. (2012) Prevalence of cervical ribs and elongated transverse processes in Saudi Arabia. Saudi Medical Journal, 33, 66-69.

Bonnet, C., Gratien, B., Ahmed, S.M., El Tayeb, M. and Simon, C. (1991) Kerma (Soudan). Genava, 39, 5-20.

Bots, J., Wijnaendts, L.C.D., Delen, S., Van Dongen, S., Heikinheimo, K. and Galis, F. (2011) Analysis of cervical ribs in a series of human fetuses. Journal of Anatomy, 219, 403-409.

Boudon-Millot, V. (2012) Galien de Pergame Un médecin grec à Rome Paris: Les Belles Lettres, Collection Histoire.

Brewin, J., Hill, M. and Ellis, H. (2009) The prevalence of cervical ribs in a London population. Clinical Anatomy, 22, 331-336.

Carretero, L. and Campo Munoz, M. (1967) Estudio radiologico y tipos morfologicos de costillas cervicales en el sexo femenino. Enferm Torax, 16, 285-308.

Castori, M., Servadei, F., Laino, L., Pascolini, G., Fabbri, R., Cifani, A.E. et al. (2016) Axial skeletogenesis in human autosomal aneuploidies: a radiographic study of 145 second trimester fetuses. American Journal of Medical Genetics Part A, 170, 676-687.

Cave, A.J.E. (1975) The morphology of the mammalian cervical pleurapophysis. Journal of Zoology of London, 177, 377-393.

Chan, K.H., Gitomer, S.A., Perkins, J.N., Liang, C. and Strain, J.D. (2013) Clinical presentation of cervical ribs in the pediatric population. Journal of Pediatrics, 162, 635-636.

Chandak, S. (2014) Usefulness of 3D CT in diagnosis of cervical rib presenting as supraclavicular swelling of short duration. Journal of Clinical and Diagnostic Research, 8, 1-2.

Chernoff, N. and Rogers, J.M. (2004) Supernumerary ribs in developmental toxicity bioassays and in human populations: incidence and biological significance. Journal of Toxicology and Environmental Health, Part B, 7, 437-449.

Crimm, P. (1952) Evaluation of a five year minifilm program. American Journal of Roentgenology Radium Therapy and Nuclear Medicine, 68 , 240-246.
Cubuk, R., Tasali, N., Arslan, G., and Atasoy, M. (2010) Arterial compression in a young adult due to the presence of a cervical rib: CT and CT angiographic findings. The Eurasian Journal of Medicine, 42, 46.

Cunningham, C., Scheuer, L. and Black, S. (2016) Developmental Juvenile Osteology, 2nd edition. Amsterdam, Netherlands: Academic Press.

Davis, D.B. and King, J.C. (1938) Cervical rib in early life. American Journal of Diseases of Children, 56, 744-755.

Davran, R., Bayarogullari, H., Atci, N., Kayali, A., Ozturk, F. and Burakgazi, G. (2017) Congenital abnormalities of the ribs: evaluation with multidetector computed tomography. The Journal of the Pakistan Medical Association, 67, 9.

Demondion, X., Herbinet, P., Van Sint, J.S., Boutry, N., Chantelot, C. and Cotten, A. (2006) Imaging assessment of thoracic outlet syndrome. Radiographics, 26, 1735-1750.

Denninger, S. (1931) Cervical ribs: a prehistoric example. American Journal of Physical Anthropology, 16, 211-214.

Dharmshaktu, G.S. and Bhandari, S.S. (2016) Prevalence and pattern of cervical rib, transversomegaly and other vertebral anomalies in normal adult cervical spine in Kumaon region of Uttarakhand, India. International Journal of Research in Orthopaedics, 2, 48-51.

Drupka, B., Wysocka, J. and Nowaczewska, W. (2019) Klippel-Feil syndrome with associated cervical rib in a human skeleton from Wągrowiec (Poland, 14th-17th centuries). International Journal of Osteoarchaeology, 29, 174-180.

Duday, H. (2009) The Archaeology of the Dead: Lectures in Archaeothanatology. Oxford, UK: Oxbow Books.

Duday, H., Courtaud, P., Crubézy, É., Sellier, P. and Tillier, A.M. (1990) L'Anthropologie "de terrain": reconnaissance et interprétation des gestes funéraires. Bulletins et mémoires de la Société d'anthropologie de Paris, 2, 29-49.

Duday, H. and Guillon, M. (2006) The role of the forensic specialist on death scene Understanding the circumstances of deposition when the body is skeletonized. In: Schmitt, A., Cunha, E. and Pinheiro, J. (Eds.) Forensic Anthropology and Forensic Medicine: Complementary Sciences from Recovery to Cause of Death. Totowa, NJ: Humana Press, pp. 117-157.

Erickson, B.R. (2015) Cervical rib causing occlusion of the subclavian artery and thoracic outlet syndrome. Journal of Vascular Medicine and Surgery, 3, 2.

Etter, L.E. (1944) Osseous abnormalities of the thoracic cage seen in forty thousand consecutive chest photoroentogenograms. American Journal of Roentgenology, 51, 359-363.

Fazekas, I.G. and Kósa, F. (1978) Forensic foetal osteology. Budapest, Hungary: Akadémiai Kiado.

Fischel, A. (1906) Untersuchungen über die Wirbelsäule und den Brustkorb des Menschen. Anatomische Hefte, 31, 462-588.

Furtado, L.V., Thaker, H.M., Erickson, L.K., Shirts, B.H. and Opitz, J.M. (2011) Cervical ribs are more prevalent in stillborn fetuses than in live-born infants and are strongly associated with fetal aneuploidy. Pediatric and Developmental Pathology, 14, 431-437.

Galis, F. (1999) Why do almost all mammals have seven cervical vertebrae? Developmental constraints, Hox genes, and cancer. Journal of Experimental Zoology, 285, 19-26.

Galis, F., Van Dooren, T.J.M., Feuth, J.D., Metz, J.A., Witkam, A., Ruinard, S., et al. (2006) Extreme selection in humans against homeotic transformations of cervical vertebrae. Evolution, 60, 2643-2654.

Geus, F. (2000) Geomorphology and prehistory of Sai island (Nubia): report on a current research project. Recent Research into the Stone Age of Northeastern Africa Studies in African Archaeology, 7, 119-128.

Gladstone, R.J. and Wakeley, C.P.G. (1932) Cervical ribs and rudimentary first thoracic ribs considered from the clinical and etiological standpoints. Journal of Anatomy, 66, 334-370.

Grier, A.L., Teich, S., Hogan, M., Caniano, D.A. and Smead, W. (2008) Pediatric thoracic outlet syndrome: a disorder with serious vascular complications. Journal of Pediatric Surgery, 43, 1089-1094. 
Gruber, W. (1869) Über die Halsripppen des Menschen mit vergleichend anatomischen Bemerkungen. Mémoires de l'Académie Impériale des Sciences de Saint-Petersboug, VIle série, tome XIII, n² SaintPetersbourg: Imperatorskaia akademiia nauk.

Gupta, A., Gupta, D.P., Saxena, D.K., and Gupta, R.P. (2012) Cervical rib: it's prevalence in Indian population around Lucknow (UP). Journal of Anatomical Society of India, 61, 189-191.

Henderson, M. (1914) Cervical rib: report of thirty-one cases. Journal of Bone and Joint Surgery, 2, 408-430.

Hershkovitz, R. (2008) Prenatal diagnosis of isolated abnormal number of ribs. Ultrasound in Obstetrics and Gynecology, 32, 506-509.

Horan, G.S.B., Nagy Kovacs, E., Behringer, R.R., and Featherstone, M.S. (1995) Mutations in paralogous Hox genes result in overlapping homeotic transformations of the axial skeleton: evidence for unique and redundant function. Developmental Biology, 169, 359-372.

Hunauld, F.J. (1742) Quaestio Medico-chirurgica, quodlibetariis disputationibus, manè discutienda M DCC XLII M Francisco-Josepho Hunauld Doctore Medico, Praeside An ab ictu, lapsu, nisuve quandoque vertebrarum Caries? PhD thesis, Paris: Université de Paris.

Hussain, M.A., Aljabri, B. and Al-Omran, M. (2016) Vascular thoracic outlet syndrome. Seminars in Thoracic and Cardiovascular Surgery, 28 151-157.

Jiang, S., Shen, H., Tan, W.Q., and Lu, H. (2019) Arterial thoracic outlet syndrome caused by cervical ribs-An unusual case report. Medicine, 98, e14778.

Keeling, J.W. and Kjaer, I. (1999) Cervical ribs: useful marker of monosomy $\mathrm{X}$ in fetal hydrops. Pediatric and Developmental Pathology, 2 , 119-123.

Krumlauf, R. (1994) Hox genes in vertebrate development. Cell, 78, 191-201.

Lanier, R.R. (1944) Length of first, twelfth, and accessory ribs in American Whites and Negroes; their relationship to certain vertebral variations. American Journal of Physical Anthropology, 2, 137-146.

Leclerc, J. (1990) La notion de sépulture. Bulletins et mémoires de la Société d'anthropologie de Paris, 2, 13-18.

Le Double, A.F. (1912) Traité des variations de la colonne vertébrale de l'homme et de leur signification au point de vue de l'anthropologie zoologique. Paris, France: Vigot frères.

Ledermann, S. (1969) Nouvelles tables-types de mortalité. Institut National d'Etudes Démographiques, Travaux et Documents n53. Paris, France: Presses Universitaires de France.

Lewis, M.E. (2007) The Bioarchaeology of Children Perspectives from Biological and Forensic Anthropology. Cambridge, UK; New York, NY: Cambridge University Press.

Lewis, M.E. (2017) Paleopathology of Children: Identification of Pathological Conditions in the Human Skeletal remains of Non-adults. Cambridge, MA: Elsevier: Academic Press.

Maureille, B. and Sellier, P. (1996) Dislocation en ordre paradoxal, momification et décomposition: observations et hypothèses. Bulletins et mémoires de la Société d'anthropologie de Paris, 8, 313-327.

McNally, E., Sandin, B. and Wilkins, R.A. (1990) The ossification of the costal element of the seventh cervical vertebra with particular reference to cervical ribs. Journal of Anatomy, 170, 125-129.

Merks, J.H.M., Smets, A.M., Van Rijn, R.R., Kobes, J., Caron, H.N., Maas, M. and Hennekam, R.C.M. (2005) Prevalence of rib anomalies in normal Caucasian children and childhood cancer patients. European Journal of Medical Genetics, 48, 113-129.

Morel, J., Pirvu, A., Elie, A., Gallet, N., Magne, J.L. and Spear, R. (2019) Functional results of cervical rib resection for thoracic outlet syndrome: impact on professional activity. Annals of Vascular Surgery, 56, 233-239.

Murail, P. and Geus, F. (2006) La nécropole 8B51 de l'île de Saï (Province du Nord, Soudan). Archéologie du Nil Moyen, 10, 181-202.

Murail, P., Maureille, B., Peressinotto, D., and Geus, F. (2004) An infant cemetery of the Classic Kerma Period (1750-1500 BC, Island of Saï, Sudan). Antiquity, 78, 267-277.
Naik, D.R., Lendon, R.G. and Barson, A.J. (1978) A radiological study of vertebral and rib malformations in children with myelomeningocele. Clinical Radiology, 29, 427-430.

O'Rahilly, R., Mulle, F. and Meyer, D.B. (1990) The human vertebral column at the end of the embryonic period proper 3 The thoracicolumbar region. Journal of Anatomy, 168, 81-93.

O'Rahilly, R. and Gardner, E. (1975) The timing and sequence of events in the development of the limbs in the human embryo. Anatomy and Embryology, 148, 1-23.

Palma, A. and Carini, F. (1990) Variation of the transverse apophysis of the 7th cervical vertebra: anatomo-radiological study of an isolated population. Italian Journal of Anatomy and Embryology, 95, 11-16.

Partiot, C. (2018) Diversité biologique des enfants décédés en période périnatale et traitements funéraires au Kerma classique-Les exemples de la nécropole 8B-51 (Kerma classique, Nord Soudan) et des cimetières de Blandy-les Tours (Xe-XIle siècle, France) et de Provins (XIle-XVIIle siècle, France). PhD thesis, Bordeaux: Université de Bordeaux.

Paterson, A. (1893) The human sacrum. Transactions of the Royal Dublin Society, 5, 123-204.

Patterson, R.H. (1940) Cervical ribs and the scalenus muscle syndrome. Annals of Surgery, 111, 531-545.

Pionnier, R. and Depraz, A. (1956) Les anomalies costales d'origine congénitale (Etude statistique d'après 10,000 radiographies). Radiol Clin, 25, 170-186

R Core Team. (2017) R: A language and environment for statistical computing [Computer software manual]. Vienna, Austria: R Foundation for Statistical Computing. Retrieved from https://ww.R-project.org/

Ray, B.S., Hardy, R. and Parsons, H. (1953) Cervical ribs: an analysis of findings in fifty-seven operative cases. Bulletin of the New York Academy of Medicine, 29, 60.

Rots, V. and Van Peer, P. (2006) Early evidence of complexity in lithic economy: core-axe production, hafting and use at Late Middle Pleistocene site 8-B-11, Sai Island (Sudan). Journal of Archaeological Science, 33, 360-371.

Sanders, R.J. and Hammond, S.L. (2002) Management of cervical ribs and anomalous first ribs causing neurogenic thoracic outlet syndrome. Journal of Vascular Surgery, 36, 51-56.

Savgaonkar, M.G., Chimmalgi, M. and Kulkarni, U.K. (2006) Anatomy of inter-scalene triangle and its role in thoracic outlet compression syndrome. Journal of the Anatomical Society of India, 55, 7-12.

Schmitt, A. and Georges, P. (2008) Quelle démarche suivre pour estimer l'âge au décès à partir du squelette. In: Charlier, P. (Ed.) Manuel Pratique de Paleopathologie Humaine. Paris, France: De Boccard, pp. 269-280.

Schumacher, R., Mai, A. and Gutjahr, P. (1992) Association of rib anomalies and malignancy in childhood. European Journal of Pediatrics, 151, 432-434.

Schut, P.C., Eggink, A.J., Boersma, M., Tibboel, D., Wijnen, R.M.H., Brosens, E., et al. (2019a) Cervical ribs and other abnormalities of the vertebral pattern in children with esophageal atresia and anorectal malformations. Pediatric Research. https://doi.org/10.1038/s4139 0-019-0631-1

Schut, P.C., Brosens, E., Galis, F., Ten Broek, C.M.A., Baijens, I.M.M., Dremmen, M.H.G., et al. (2019b) Abnormal vertebral patterns in genetically heterogeneous deceased fetuses and neonates: evidence of selection against variations. bioRxiv, 784926 .

Sellier, P., Tillier, A.M. and Bruzek, J. (1997) À la recherche d'une référence pour l'estimation de l'âge des fœtus, nouveau-nés et nourrissons. Anth Préhis, 108, 75-87.

Sharma, D., Sharma, V. and Rathore, M. (2014) Prevalence of "cervical rib" and its association with gender, body side, handedness and other thoracic bony anomalies in a population of Central India. Indian Journal of Basic and Applied Medical Research, 3, 593-597.

Simon, C. (1980) Etude anthropologique préliminaire sur le matériel de Kerma (Soudan). Genava, 28, 6567. 
Singh, H.K. (1973) Incidence of congenital rib anomalies. Indian J Chest Dis, 15, 157-164.

Southam, A.H. and Bythell, W.J.S. (1924) Cervical ribs in children. British Medical Journal, 2, 844-845.

Spadliński, Ł., Cecot, T., Majos, A.,Stefańczyk, L., Pietruszewska, W., Wysiadecki, G. et al. (2016) The epidemiological, morphological, and clinical aspects of the cervical ribs in humans. BioMed Research International, 2016, 1-7.

Staderini, R. (1894) Ricerche statistische sulla frequenza delle varieta numeriche delle vertebre nell'uomo. Monitore Zooligo Italiano, 5, 56-95.

Steiner, H.A. (1943) Roentgenologic manifestations and clinical symptoms of rib abnormalities. Radiol, 40, 175-178.

Sycamore, L.K. (1944) Common congenital anomalies of the bony thorax. American Journal of Roentgenology, 51, 593-599.

ten Broek, C.M.A., Bakker, A.J., Varela-Lasheras, I., Bugiani, M., Van Dongon, S. and Galis, F. (2012) Evo-Devo of the human vertebral column: on homeotic transformations, pathologies and prenatal selection. Evolutionary Biology, 39, 456-471.

Thompson, T. (1910) Cervical ribs. Proceedings of the Royal Society of Medicine, 3(Clin_Sect), 155-156.

Todd, T.W. (1912) "Cervical rib": factors controlling its presence and its size its bearing on the morphology and development of the shoulder. Journal of Anatomy Physiology, 46, 244-288.

Topinard, P. (1877) Des anomalies de nombre de la colonne vertébrale chez l'homme. Review of Anthropology, 6, 575-659.

Tzou, C.H., Paternostro-Sluga, T., Frey, M., and Aszmann, O.C. (2014a) Can obstetrical brachial plexus palsy be caused by a cervical rib? European Surgery, 46, 118-127.

Tzou, C.H.J., Paternostro-Sluga, T., Frey, M., and Aszmann, O.C. (2014b) Birth brachial plexus palsy caused by cervical rib. Journal of Plastic, Reconstructive \& Aesthetic Surgery, 67, 1004-1005.

Van der Geer, A.A.E. and Galis, F. (2017) High incidence of cervical ribs indicates vulnerable condition in Late Pleistocene woolly rhinoceroses. PeerJ, 5, e3684.
Van Peer, P., Fullagar, R., Stokes, S.,Bailey, R.M., Moeyersons, J., Steenhoudt, F. et al. (2003) The Early to Middle Stone Age transition and the emergence of modern human behaviour at site 8-B11, Sai Island, Suda n. Journal of Human Evolution, 45, 187-193.

Vercellio, G., Baraldini, V., Gatti, C., and Cipolat, L. (2003) Thoracic outlet syndrome in paediatrics: clinical presentation, surgical treatment, and outcome in a series of eight children. Journal of Pediatric Surgery, 38, 58-61.

Verna, E. (2014) Les Variations osseuses asymptomatiques du squelette postcranien: leur contribution à l'identification en anthropologie médico-légale. PhD thesis, Marseille: Université d'Aix-Marseille.

Viertel, V.G., Intrapiromkul, J., Maluf, F., Patel, N.V., Zheng, W., Alluwaimi, F. et al. (2012) Cervical ribs: a common variant overlooked in CT imaging. American Journal of Neuroradiology, 33, 2191-2194.

Weston, W.J. (1956) Genetically determined cervical rib. A family study. British Journal of Radiology, 29, 455-456.

\section{SUPPORTING INFORMATION}

Additional supporting information may be found online in the Supporting Information section.

How to cite this article: Partiot C, Guillon M, Peressinotto D, Castex D, Maureille B. Cervical ribs in human early life: morphological variability and first identification as a morbidity criterion in a past population. J. Anat. 2020;237:119-132. https://doi.org/10.1111/joa.13178 